\title{
Correction to: The impact of unilateral diaphragmatic paralysis on sleepdisordered breathing: a scoping review
}

\section{L'impact de la paralysie diaphragmatique unilatérale sur les troubles respiratoires du sommeil : une revue exploratoire}

\author{
Mandeep Singh, MBBS, MD, MSc (D) - Jorge M. Mejia, MD • Dennis Auckley, MD • Faraj Abdallah, MD • \\ Christopher Li, MD • Vivek Kumar, MD • Marina Englesakis, MLIS • Richard Brull, MD
}

Published online: 7 April 2021

(C) Canadian Anesthesiologists' Society 2021

\section{Can J Anesth/J Can Anesth \\ https://doi.org/10.1007/s12630-021-01970-y}

This article was updated to replace Fig. 1.
Publisher's Note Springer Nature remains neutral with regard to jurisdictional claims in published maps and institutional affiliations.
The original article can be found online at https://doi.org/10.1007/ s12630-021-01970-y.

M. Singh, MBBS, MD, MSc ( $\square) \cdot$ J. M. Mejia, MD .

R. Brull, MD

Department of Anesthesiology and Pain Management, Women's College Hospital, Toronto, ON, Canada

e-mail: mandeep.singh@uhn.ca

Department of Anesthesiology and Pain Management, Toronto Western Hospital, University Health Network, University of Toronto, 399 Bathurst Street, McL 2-405, Toronto, ON M5T 2S8, Canada

D. Auckley, MD

Division of Pulmonary, Critical Care and Sleep Medicine, MetroHealth Medical Center, Case Western Reserve University School of Medicine, Cleveland, OH, USA
F. Abdallah, MD

Department of Anesthesia, University of Ottawa, Ottawa, ON, Canada

\section{Li, MD}

Department of Respirology, St. Michael's Hospital, Unity Health, Toronto, ON, Canada

V. Kumar, MD · M. Englesakis, MLIS

Department of Anesthesiology and Pain Management, Toronto Western Hospital, University Health Network, University of Toronto, 399 Bathurst Street, McL 2-405, Toronto, ON M5T 2S8, Canada 